\title{
A new physically-based quantification of marine isoprene and primary organic aerosol emissions
}

\author{
B. Gantt, N. Meskhidze, and D. Kamykowski \\ North Carolina State University, Raleigh, NC, USA \\ Received: 9 December 2008 - Published in Atmos. Chem. Phys. Discuss.: 29 January 2009 \\ Revised: 6 May 2009 - Accepted: 9 July 2009 - Published: 24 July 2009
}

\begin{abstract}
The global marine sources of organic carbon (OC) are estimated here using a physically-based parameterization for the emission of marine isoprene and primary organic matter. The marine isoprene emission model incorporates new physical parameters such as light sensitivity of phytoplankton isoprene production and dynamic euphotic depth to simulate hourly marine isoprene emissions totaling $0.92 \mathrm{Tg}$ $\mathrm{C} \mathrm{yr}^{-1}$. Sensitivity studies using different schemes for the euphotic zone depth and ocean phytoplankton speciation produce the upper and the lower range of marine-isoprene emissions of 0.31 to $1.09 \mathrm{Tg} \mathrm{C} \mathrm{yr}^{-1}$, respectively. Established relationships between sea spray fractionation of waterinsoluble organic carbon (WIOC) and chlorophyll- $a$ concentration are used to estimate the total primary sources of marine sub- and super-micron OC of 2.9 and 19.4 $\mathrm{Tg} \mathrm{C} \mathrm{yr}^{-1}$, respectively. The consistent spatial and temporal resolution of the two emission types allow us, for the first time, to explore the relative contributions of sub- and super-micron organic matter and marine isoprene-derived secondary organic aerosol (SOA) to the total OC fraction of marine aerosol. Using a fixed $3 \%$ mass yield for the conversion of isoprene to SOA, our emission simulations show minor $(<0.2 \%)$ contribution of marine isoprene to the total marine source of OC on a global scale. However, our model calculations also indicate that over the tropical oceanic regions $\left(30^{\circ} \mathrm{S}\right.$ to $\left.30^{\circ} \mathrm{N}\right)$, marine isoprene SOA may contribute over $30 \%$ of the total monthlyaveraged sub-micron $\mathrm{OC}$ fraction of marine aerosol. The estimated contribution of marine isoprene SOA to hourlyaveraged sub-micron marine OC emission is even higher, approaching $50 \%$ over the vast regions of the oceans during the midday hours when isoprene emissions are highest. As it is widely believed that sub-micron OC has the potential to influence the cloud droplet activation of marine aerosols, our
\end{abstract}

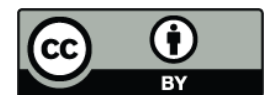

Correspondence to: N. Meskhidze (nmeskhidze@ncsu.edu) findings suggest that marine isoprene SOA could play critical role in modulating properties of shallow marine clouds and influencing the climate.

\section{Introduction}

Marine aerosols strongly affect properties and lifetime of stratiform clouds, influencing Earth's radiation budget and climate. Established sources of marine aerosol include primary emission of sea-salt particles and dimethyl sulfide (DMS), the atmospheric oxidation of which is a major source of non-sea-salt (nss) sulfate in remote marine air (Shaw, 1983; Andreae et al., 1986; Charlson et al., 1987; O'Dowd et al., 1997). It has also been proposed that primary emissions of biogenic organic matter, bacterial and viral debris from wave breaking (Middlebrook et al., 1998; O'Dowd et al., 2004), and secondary organic aerosol (SOA) from phytoplankton-emitted biogenic volatile organic compounds (BVOCs) (O'Dowd et al., 2002; Meskhidze and Nenes, 2006; O'Dowd and de Leeuw, 2007) can act synergistically with the established mechanisms, leading to changes in marine aerosol chemical composition and number concentration. Significant abundances of organic carbon (OC) aerosols have been observed in marine environments (Novakov et al., 1997; Putaud et al., 2000; Cavalli et al., 2004; Yoon et al., 2007; Pio et al., 2007), particularly over the regions of enhanced oceanic biological activity (O'Dowd et al., 2004). Despite the significant progress in the recent decade, the mechanism and the magnitude of the marine OC sources are still highly uncertain, and the role of oceanic biota in modifying chemical composition and size distribution of marine cloud condensation nuclei $(\mathrm{CCN})$ remains one of the most intriguing questions in the climate studies.

Marine organic aerosols appear to have two distinctly different sources which can be broadly classified as primary or secondary. Primary marine organic aerosols of biogenic

Published by Copernicus Publications on behalf of the European Geosciences Union. 
Table 1. Global annual total marine emissions of isoprene and organic carbon aerosols.

\begin{tabular}{|c|c|c|c|}
\hline Global marine emissions & Average estimate & Type & Ref. \\
\hline \multirow{6}{*}{ 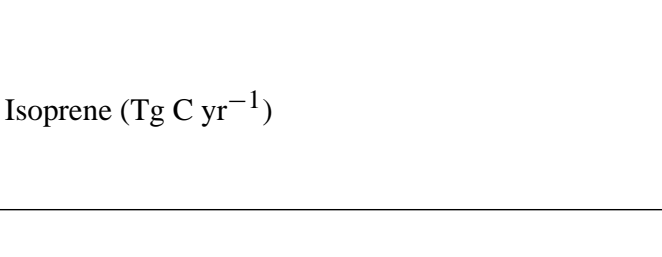 } & 1.1 & In-situ & Bonsang et al. (1992) \\
\hline & 0.1 & Remote Sensing & Palmer and Shaw (2005) \\
\hline & 1.2 & In-situ & Sinha et al. (2007) \\
\hline & 0.27 & Remote Sensing & Arnold et al. (2009) \\
\hline & 1.68 & Modeling & Arnold et al. (2009) \\
\hline & 0.92 & Remote Sensing & This work \\
\hline \multirow{3}{*}{ Sub-micron Primary Organic Carbon $\left(\mathrm{Tg} \mathrm{C} \mathrm{yr}^{-1}\right)$} & 5.5 & Remote Sensing & Spracklen et al. (2008) \\
\hline & 2.5 & Remote Sensing & Langmann et al. (2008) \\
\hline & 2.9 & Remote Sensing & This work \\
\hline Super-micron Primary Organic Carbon $\left(\mathrm{Tg} \mathrm{C} \mathrm{yr}^{-1}\right)$ & 19.4 & Remote Sensing & This work \\
\hline \multirow{3}{*}{ Total Organic Carbon $\left(\mathrm{Tg} \mathrm{C} \mathrm{yr}^{-1}\right)$} & 8 & Remote Sensing & Spracklen et al. (2008) \\
\hline & 75 & Modeling & Roelofs (2008) \\
\hline & 22.3 & Remote Sensing & This work \\
\hline
\end{tabular}

origin are emitted from the ocean by the bubble bursting process, forming internally mixed aerosol of sea-salt and organics (Middlebrook et al., 1998; Cavalli et al., 2004). Primary marine organic aerosols, especially in the sub-micron diameter size range, are typically comprised of insoluble surface active organic colloids and aggregates (Blanchard, 1964; Gershey, 1983; Leck and Bigg, 2005; Facchini et al., 2008). Analyses of marine aerosol chemical composition show that during the periods of high ocean productivity, concentration of water insoluble organic aerosols in the accumulation mode increase by almost a factor of 10 (from 0.07 to $0.62 \mu \mathrm{g} \mathrm{m}^{-3}$ ) and comprise up to $45 \%$ of the total sub-micron aerosol mass in the marine air (O’Dowd et al., 2004).

Secondary organic aerosols of marine origin can be formed by the oxidation of phytoplankton-emitted BVOC. Out of multiple BVOC emitted by phytoplankton, including DMS, halocarbons, isoprene, and monoterpenes (Shaw et al., 1983; Tokarczyk et al., 1994; Bonsang et al., 1992; Yassaa et al., 2008), in this study we focus on marine emissions of isoprene. Photooxidation of isoprene has been shown to lead to the formation of SOA (Claeys et al., 2004). Recent laboratory chamber studies show that SOA yields (defined as the ratio of the mass of SOA formed to the mass of isoprene reacted) are 1-2\% at high $\mathrm{NO}_{\mathrm{x}}$ levels (Kroll et al., 2005), 3\% at low $\mathrm{NO}_{\mathrm{x}}$ levels (Kroll et al., 2006) and up to $24 \%$ from the reaction of isoprene with the nitrate radicals ( $\mathrm{Ng}$ et al., 2008). Aqueous phase chemical processes offer additional SOA production pathways increasing the SOA yields up to $42 \%$ (Ervens et al., 2008). Further uncertainties in the assessments of global marine SOA sources arise from the fact that marine isoprene emissions and isoprene concentrations in the marine boundary layer have been shown to be related to sunlight (Lewis et al., 2001; Shaw et al., 2003; Liakakou et al., 2007; Sinha et al., 2007), temperature (Shaw et al.,
2003) and species of phytoplankton (Shaw et al., 2003). The current estimates for global marine isoprene emissions range between $0.10-1.68 \mathrm{Tg} \mathrm{C} \mathrm{yr}^{-1}\left(0.11-1.9 \mathrm{Tg} \mathrm{yr}^{-1}\right)$ based on global extrapolations of in-situ measurements (Bonsang et al., 1992; Sinha et al., 2007), satellite observations (Palmer and Shaw, 2005; Arnold et al., 2009), and modeling studies (Arnold et al., 2009). These estimates are summarized in Table 1.

There have been some recent advances in the modeling of marine organic aerosol emissions and their impact on clouds. Roelofs (2008) demonstrated that the inclusion of marine organic aerosols in a climate model decreases the predicted cloud droplet effective radii, increases droplet number concentration and results in better agreement with satellite measurements over marine areas. Spracklen et al. (2008) used back trajectory-weighted satellite-derived chlorophyll- $a$ concentrations ([Chl- $a]$ ) and two global chemical transport models to create marine OC emissions, concluding that the marine source is a globally significant source of OC, comparable to that of fossil fuels. O'Dowd et al. (2008) produced a combined organic/inorganic sea spray function to estimate marine primary organic aerosols emissions and found better model-predicted aerosol mass concentration over coastal areas. Langmann et al. (2008) extended these marine primary organic emissions to the global scale. Arnold et al. (2009) used new laboratory measurements of isoprene production, satellite-derived phytoplankton speciation, and top-down modeling to constrain global marine isoprene emissions. They found that marine isoprene does not make up a significant portion of the global OC budget at several marine sites and concluded that marine isoprene does not have a large role in affecting global marine aerosol abundance. Table 1 summarizes reported global OC emissions estimates. In this study, we use new laboratory 
measurements of isoprene production by phytoplankton under a range of light conditions, as well as surface wind and $[\mathrm{Chl}-a]$-dependent emissions of marine primary organic aerosols, to create high temporal resolution global emission maps of marine isoprene and primary $\mathrm{OC}$ aerosols.

\section{Methods}

\subsection{Phytoplankton cultures and chlorophyll analysis}

Three diatom strains, Thalassiosira weissflogii (CCMP 1336), Thalassiosira pseudonana (CCMP 1335), and Chaetoceros neogracile (CCMP 1318), and a coccolithophore Emiliania huxleyi (CCMP 375) were grown on L1-based (Sigma-Aldrich) medium in a climate-controlled room with constant temperature and light conditions of $22^{\circ} \mathrm{C}$ and $\sim 90 \mu \mathrm{E} \mathrm{m}^{-2} \mathrm{~s}^{-1}$, respectively, to replicate optimal growing conditions. These well-studied species were primarily chosen for their abundance; however, C. neogracile and $E$. huxleyi were also selected due to the availability of reported laboratory measurements (Shaw et al., 2003; Colomb et al., 2008), that were used for intercomparison with our data. The seawater and nutrients were prepared for culturing by autoclaving overnight to remove bacterial contamination. Cultures were grown in 11 Erlenmeyer flasks covered with aluminum foil allowing air transfer to prevent carbon dioxide limitation. Prior to the experiment, $20 \mathrm{ml}$ samples were transferred onto Whatman GF/F filters under vacuum and stored in freezer for later analysis of [Chl- $a$ ]. Chlorophyll- $a$ was extracted with $90 \%$ acetone and concentration determined following the method of Holm-Hansen and Riemann (1978) using a Turner fluorometer model \#450.

\subsection{Isoprene measurements}

After an incubation period ranging from 7-14 days, $30 \mathrm{ml}$ aliquots of the dense phytoplankton cultures were transferred to Wheaton $40 \mathrm{ml}$ EPA glass vials and sealed using opentop screw caps with $10 \mathrm{~mm}$ PTFE and $90 \mathrm{~mm}$ silicone septa. The $10 \mathrm{ml}$ of headspace remaining above the sample maximized concentrations of isoprene emitted by the phytoplankton while ensuring that $\mathrm{CO}_{2}$ limitation did not occur during the experiment. To assess the effect of changing incoming solar radiation for isoprene production, the phytoplankton were exposed to various levels of light intensity ranging from 0 to $1200 \mu \mathrm{E} \mathrm{m}^{-2} \mathrm{~s}^{-1}\left(\sim 0\right.$ to $\left.600 \mathrm{~W} \mathrm{~m}^{-2}\right)$ for up to eight hours under a constant temperature of $\sim 22^{\circ} \mathrm{C}$ controlled by a Neslab CFT-33 Refrigerated Recirculator (Thermo Fisher Scientific, Waltham, MA). The samples were suspended over 6 halogen lights (Philips 250 W Projector Lamp \#13095) in a water bath with circulating water to absorb heat from the lights. Photosynthetically active radiation (PAR) inside the water bath was measured by QSL-100 Laboratory Quantum Scalar Irradiance Meter (Biospherical Instruments, San Diego, CA). The intensity of light reaching the samples was controlled by lining the bottom of the water bath with several layers of semi-translucent fiberglass screen. Prior calibration testing revealed that each layer of the screen absorbed approximately half of the incoming light.

Laboratory measurements of isoprene concentrations were taken using headspace gas chromatography with a Photovac Voyager (Photovac, Inc., Waltham, MA) portable GC with a photoionization detector (PID) at the North Carolina State University campus in Raleigh, NC. Ultra high-purity nitrogen was used as a carrier gas. The system was calibrated against a standard containing 103.2 $\pm 10.3 \mathrm{ppb}(\mathrm{v} / \mathrm{v})$ isoprene in ultrapure nitrogen (Scott-Marrin Inc., Riverside, CA). The detector output is linear from 0 to $460 \mathrm{ppb} / \mathrm{v}$ isoprene concentration with an intercept through zero (Geron et al., 2006). We estimate that both precision and accuracy were within 5\% as determined by repeated measurements of the standard gas and inter-calibration against PTR-MS (Proton Transfer Reaction Mass Spectrometry) during intensive field study at the University of Virginia at Charlottesville. According to the instrument calibration records carried out at Photovac, Inc., the lower detection limit of our analytical system is $3 \mathrm{ppbv}$. Using a Hamilton Gastight \#1750 syringe, $500 \mu \mathrm{L}$ of the headspace from each sample were injected in the gas sample loop with 0.5 to $1.5 \mathrm{~h}$ intervals to monitor the changes in isoprene concentrations inside the sealed vials. Column temperature was isothermal at $60^{\circ} \mathrm{C}$ and pressure was constant at 6 psi. During each experiment, we kept several phytoplankton samples in the dark and observed isoprene concentration levels that were below the detection limit. This indicates that like Prochlorococcus (Shaw et al., 2003), isoprene production from selected diatom and coccolithophore species were negligible under nighttime conditions. The isoprene concentrations from the headspace of blank seawater samples were measured and used as the background air that was subtracted from the phytoplankton sample measurements. Background isoprene concentrations were below the detection limit $(<3 \mathrm{ppb})$ in the laboratory measurements, while the measured isoprene mixing ratio ranged between 5 and $20 \mathrm{ppb}$.

Comparison of [Chl-a]-normalized isoprene production rates and PAR showed that for all types of phytoplankton tested in this work, isoprene production rates increase under increasing light intensity with a rapid increase at low levels and gradual increases at high levels of irradiance. This pattern of isoprene production is similar to that of terrestrial vegetation (Guenther et al., 1991; Guenther et al., 1993) and previous phytoplankton measurements (Shaw et al., 2003). The diamonds on Fig. 1 show the mean of all measurements for a given light intensity for the diatoms species and E. huxleyi, which represents coccolithophores. The error bars indicate one standard deviation of the measurements for each phytoplankton group. There are several possible reasons for the wide range in production rates not quantified in this study, including phytoplankton senescence or photoinhibition of marine phytoplankton photosynthesis (Shaw et al., 


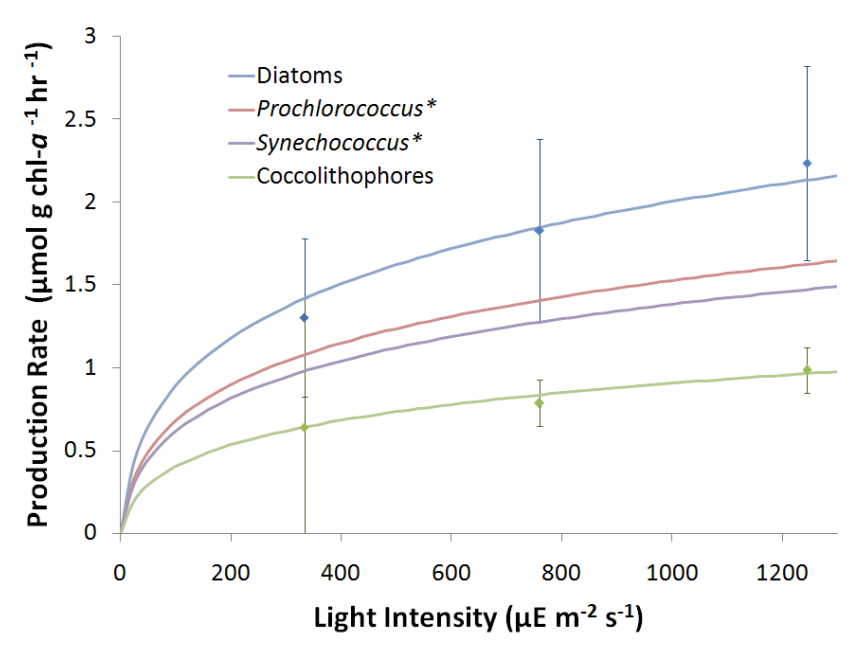

Fig. 1. Isoprene production rates as a function of light intensity for various phytoplankton groups. Production rates from phytoplankton species with * were estimated based on production rates from Shaw et al. (2003) of $1.5 \pm 0.9 \mu \mathrm{mol}$ isoprene $(\mathrm{g} \mathrm{Chl}-a)^{-1}$ day $^{-1}$ and $1.4 \mu \mathrm{mol}$ isoprene (g Chl- $a)^{-1} \mathrm{day}^{-1}$ for Prochlorococcus and Synechococcus respectively. Error bars denote one standard deviation of species-specific isoprene production rates measured for different levels of light intensity.

2003). Amongst the diatoms, C. neogracile had the highest isoprene production, followed by $T$. weissflogii and then T. pseudonana, respectively. We observed that each of the diatom species had higher isoprene production rates than that of E. huxleyi, a result similar to that of Shaw et al. (2003) and Columb et al. (2008) which both reported the highest $[\mathrm{Chl}-a]$-normalized isoprene production rate from a diatom species. A log squared curve, multiplied by a constant emission factor (EF) unique to each phytoplankton group, was used to fit the measurements. The EF for Prochlorococcus, Synechococcus, and others are estimated by comparing the daily isoprene production rates from Shaw et al. (2003) for several species taken at PAR values of $90 \mu \mathrm{E} \mathrm{m}^{-2} \mathrm{~s}^{-1}$, converting these daily rates to hourly, and assuming a similar log squared relationship between PAR and isoprene production as that observed for diatoms and coccolithophores for variable light intensities. The isoprene production rates $P$ ( $\mu$ mole isoprene (gram chlorophyll $a)^{-1} \mathrm{~h}^{-1}$ ) are given by the equation:

$P=E F * \ln (I)^{2}$

where $I$ is the ambient PAR $\left(\mu \mathrm{E} \mathrm{m}^{-2} \mathrm{~s}^{-1}\right)$ and $E F$ ( $\mu \mathrm{mol}$ isoprene $(\mathrm{g} \mathrm{Chl}-a)^{-1} \mathrm{~h}^{-1}$ ) has the following values: 0.042 for diatoms, 0.032 for Prochlorococcus, 0.029 for Synechococcus, 0.019 for coccolithophores, and 0.028 for other phytoplankton) and $I$ is the ambient $\operatorname{PAR}\left(\mu \mathrm{E} \mathrm{m}^{-2} \mathrm{~s}^{-1}\right)$.

\subsection{Phytoplankton speciation}

Global phytoplankton speciation is estimated by using two distinct methods: the PHYSAT (Alvain et al., 2005, 2008), and the nutrient depleting temperature (NDT) (Kamykowski et al., 2002). In the PHYSAT method, satellite-derived normalized water-leaving radiances (nLw) from 5 different wavelengths are compared to the lookup tables of average $\mathrm{nLw}\left(\mathrm{nLw}^{*}\right)$ for each wavelength based on [Chl- $a$ ]. Speciation is determined based on the unique effects on satellite-observed $\mathrm{nLw}$ by the pigments of each phytoplankton class. The global monthly maps of $\mathrm{nLw}$ data at $1^{\circ}$ latitude $\times 1^{\circ}$ longitude $\left(1^{\circ} \times 1^{\circ}\right)$ resolution were created by regridding the Sea-viewing Wide Field-of-view Sensor (SeaWiFS) monthly-averaged $\sim 9 \mathrm{~km}$ resolution $\mathrm{nLw}$ data for the year 2001. By comparing the obtained $\mathrm{nLw}$ data with the lookup tables of $\mathrm{nLw}^{*}$, the following dominant phytoplankton classes were identified: nanoeukaryotes, Prochlorococcus, Synechococcus, diatoms, and Phaeocystis-like plankton/coccolithophores. In the NDT method, seasonal and inter-annual nutrient (i.e., nitrate, phosphate, silicate and iron) variability and remotely sensed [Chl-a] data is used to infer the likely phytoplankton cell size and taxonomic composition (Kamykowski et al., 2002). SeaWiFS monthlyaveraged $\sim 9 \mathrm{~km}$ resolution sea surface temperature (SST) was regridded to $1^{\circ} \times 1^{\circ}$ and compared to NDT tables of nutrient categories (Kamykowski et al., 2002) to create global monthly maps of phytoplankton classes for year 2001. The two methods (PHYSAT and NDT) show general agreement in the spatial and temporal distribution of phytoplankton speciation (see Figs. S2, S3: http://www.atmos-chem-phys.net/ 9/4915/2009/acp-9-4915-2009-supplement.pdf). In tropical waters $\left(30^{\circ} \mathrm{S}\right.$ to $\left.30^{\circ} \mathrm{N}\right)$ both methods show small-celled phytoplankton (e.g., Prochlorococcus, Synechococcus, and nanoeukaryotes) dominate. However, in mid-latitude waters $\left(60^{\circ} \mathrm{S}\right.$ to $30^{\circ} \mathrm{S}$ and $30^{\circ} \mathrm{N}$ to $\left.60^{\circ} \mathrm{N}\right)$ each method predicts higher abundance of diatoms. In this study, the PHYSAT model is used as a default for the assessments of the global marine-isoprene emissions because it directly represents the dominant phytoplankton groups rather than using a proxy as in the NDT method. In addition, the PHYSAT method differentiates between Prochlorococcus, Synechococcus, and nanoeukaryotes, while the NDT method does not. Recently, PHYSAT has been proven successful in characterizing changes in the dominant phytoplankton group during the crossing of oceanic fronts in the Southern Indian Ocean (Colomb et al., 2009). In Sect. 4.1 we present sensitivity calculations using NDT method to estimate how distinct methods and the uncertainties in phytoplankton community composition can affect our results for the total global oceanic emissions of isoprene. 


\subsection{Marine isoprene emissions}

Estimated isoprene production rates for some of the major phytoplankton species under variable light intensity described in Sect. 2.2 were used to create global maps of oceanic isoprene emission. The amount of solar radiation received by phytoplankton at different depths of the water column is calculated using hourly $1^{\circ} \times 1^{\circ}$ all-sky surface incoming solar radiation $I_{o}\left(\mathrm{~W} \mathrm{~m}^{-2}\right)$ from the Global Weather Research and Forecasting Model (G-WRF) v. 3.0 (Richardson et al., 2007). Total solar radiation in units of $\mathrm{W} \mathrm{m}^{-2}$ was converted to PAR measurements in units of $\mu \mathrm{E} \mathrm{m}^{-2} \mathrm{~s}^{-1}$ by using the following approximate conversion: $1 \mathrm{~W} \mathrm{~m}^{-2} \approx 2 \mu \mathrm{E} \mathrm{m}^{-2} \mathrm{~s}^{-1}$ (Jacovides et al., 2004). The values of downwelling irradiance within a water column were characterized using the diffuse attenuation coefficient values at $490 \mathrm{~nm} k_{490}\left(\mathrm{~m}^{-1}\right)$ obtained from the SeaWiFS satellite (O'Reilly et al., 1998) and regridded to $1^{\circ} \times 1^{\circ}$. The light propagation throughout the water column with depth $h$ (meters) is estimated by applying Beer-Lambert's Law, given by: $I=I_{0} e^{-k / h}$. The total water depth $H_{\max }$, through which isoprene production can occur in our model was assumed to extend from the surface to the point at which the light levels are reduced to $2.5 \mathrm{~W} \mathrm{~m}^{-2}$, which is the level at which the photosynthesis ceases in Prochlorococcus (Shaw et al., 2003). This depth, which represents the maximum possible extent of the planktonic euphotic zone, is determined using the following equation:

$H_{\max }=\left(-\ln \left(\frac{2.5}{I_{o}}\right) * k_{490}^{-1}\right)$

Because $H_{\max }$ is dependent on incoming solar radiation, it is dynamic throughout the day with a midday maxima and a depth of zero at night. Typical midday values for $H_{\max }$ range from $5 \mathrm{~m}$ in near coastal waters to $300 \mathrm{~m}$ in remote oligotrophic waters. This is the first time when dynamic euphotic depth is used for modeling marine isoprene production. Calculations documenting the sensitivity of our global marine-isoprene emissions to selection of the euphotic zone depth are presented in Sect. 4.2.

The total column isoprene emission $E_{\text {iso }}\left(\mu\right.$ mole $\left.^{-1}\right)$ is found by integrating Eq. (1) for the euphotic zone of $H_{\max }$ :

$$
E_{\mathrm{iso}}=S A * H_{\max } *[\mathrm{Chl}-a] * F_{\text {iso }} * \int_{0}^{H_{\max }} p d h
$$

Here $S A$ is the surface area of the $1^{\circ} \times 1^{\circ}$ grid cell $\left(\mathrm{m}^{2}\right)$ and $F_{\text {iso }}$ is the emission fraction (i.e., fraction of water column produced isoprene that is emitted to the atmosphere) and $[\mathrm{Chl}-a]\left(\mathrm{mg} \mathrm{m}^{-3}\right)$ was derived from monthly-average, $\sim 9 \mathrm{~km}$, Level 3 SeaWiFS data (O'Reilly et al., 1998). SeaWiFS was shown to have accurate retrieval of surface [Chl- $a$ ] in coastal as well as remote oceanic sites (Blondeau-Patissier et al., 2004). The emission fraction is calculated as the ratio of sea-air emissions of isoprene to total isoprene loss in the water column from chemical, biological, and ocean-air exchange following the method of Palmer and Shaw (2005). In this formulation, it is assumed that the light at depth will continue to diffuse at a rate identical to the surface diffuse attenuation retrieved by SeaWiFS and that the [Chl- $a$ ] is constant throughout $H_{\max }$. Extrapolating these satellite-derived surface water properties to waters below one optical depth is unrealistic, and some overestimation of [Chl-a] and $k_{490}$ is likely.

Overall, there are two main differences between our $E_{\text {iso }}$ formulation and that of previously published studies (e.g., Palmer and Shaw, 2005; Arnold et al., 2009): 1) the use of a dynamic $H_{\max }$ based on hourly modeled $I_{o}$ and satellite derived $k_{490}$ as opposed to taking a mixed layer depth based on climatology, and 2) the integration of light-sensitive speciesdependent isoprene production rates throughout $H_{\max }$ as opposed to a constant (or species-dependent but fixed) isoprene production rate.

\subsection{Marine primary organic aerosol emissions}

Chemical analyses of marine aerosols show that OC residing in the sub- and super-micron modes of sea-spray particles has considerably different water solubility (Facchini et al., 2008). While water-insoluble organic carbon (WIOC) comprises the major portion $(94 \pm 4 \%)$ of sub-micron OC particles, watersoluble organic carbon (WSOC) contributes more than onethird $(33 \pm 3 \%)$ of total carbon in the coarse size fraction of marine aerosols (Facchini et al., 2008). Here the global marine primary $\mathrm{OC}$ emissions are estimated separately in suband super-micron range. Over the productive regions of the oceans, the sub-micron marine aerosol mass was shown to be dominated by insoluble organics, while the super-micron aerosols were dominated by sea-salt (Facchini et al., 2008). The sub-micron mass emission rate $E_{\text {sub }}\left(\mathrm{ng} \mathrm{m}^{-2} \mathrm{~s}^{-1}\right)$ of marine primary organic aerosols is obtained by multiplying the mass emission rate of marine particles less than $1 \mu \mathrm{m}$ in diameter from Ceburnis et al. (2008) (determined using 22 meter wind speed) by $F_{\text {sub }}$, the chlorophyll-dependent mass contribution of WIOC in sub-micron sea-spray aerosols from O'Dowd et al. (2008):

$$
\begin{aligned}
E_{\text {sub }}= & 9.6 \times 10^{-5} \\
& *\left(U_{10} *\left(1+\frac{0.0012^{0.5}}{0.4} * \ln \left(\frac{22}{10}\right)\right)\right)^{4.23} \\
& * F_{\text {sub }},
\end{aligned}
$$

when $U_{10} \leq 11 \mathrm{~m} \mathrm{~s}^{-1}$

$$
\begin{aligned}
E_{\mathrm{sub}}= & 9.6 \times 10^{-5} *\left(U_{10}\right. \\
& *\left(1+\frac{\left(\left(0.49+0.065 * U_{10}\right) \times 10^{-3}\right)^{0.5}}{0.4}\right. \\
& \left.\left.* \ln \left(\frac{22}{10}\right)\right)\right)^{4.23} * F_{\text {sub }},
\end{aligned}
$$




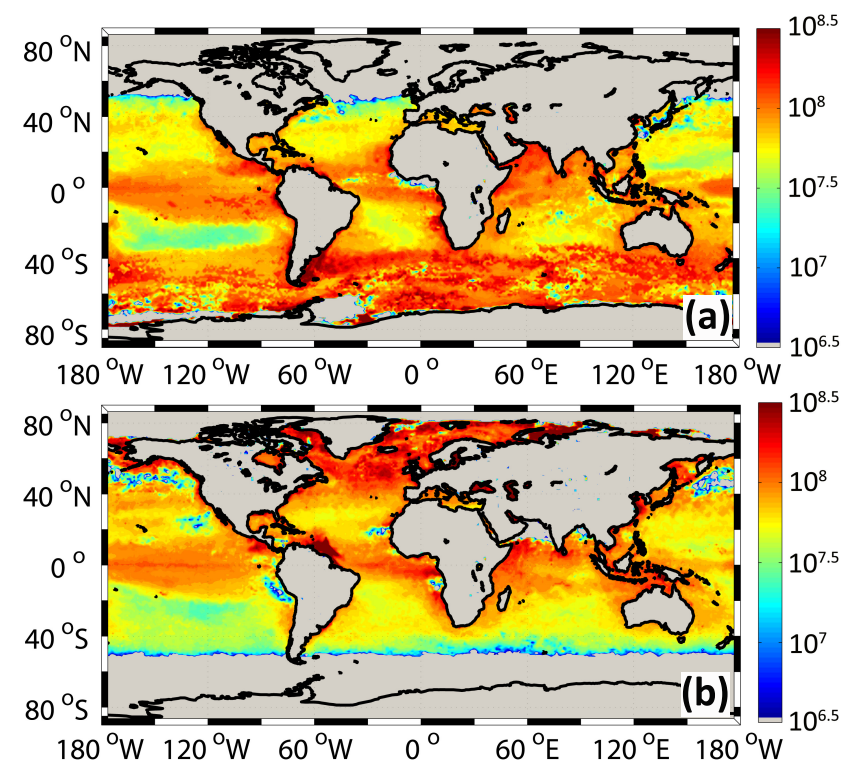

Fig. 2. Monthly-averaged marine isoprene emission rate (molecules $\mathrm{cm}^{-2} \mathrm{~s}^{-1}$ ) for (a) January and (b) July 2001.

when $U_{10}>11 \mathrm{~m} \mathrm{~s}^{-1}$, where $U_{10}$ is the wind speed at $10 \mathrm{~m}$ above the water surface $\left(\mathrm{m} \mathrm{s}^{-1}\right)$ and $F_{\text {sub }}=0.63[\mathrm{Chl}-a]+0.1$ (O'Dowd et al., 2008). In this formulation, we convert the $22 \mathrm{~m}$ wind speed used in Ceburnis et al. (2008) to $U_{10}$ by applying the correction factor from Andreas (1998) which assumes neutral stability and uses a logarithmic wind profile with height. The $U_{10}$ was obtained using 4-times daily $10 \mathrm{~m}$ wind velocity from the National Centers for Environmental Prediction (NCEP) Reanalysis (http://www.cdc.noaa. gov/cdc/reanalysis/) for the year 2001 and spatially interpolated the data to $1^{\circ} \times 1^{\circ}$. The organic matter $(\mathrm{OM})$ emission rate was converted to an $\mathrm{OC}$ emission rate by using the $\mathrm{OC}$ to OM conversion factor of 1.4 (Decesari et al., 2007; Facchini et al., 2008).

The super-micron primary organic mass emission rate is calculated in a way similar to the sub-micron emission rate, though using a different sea-spray function and an organic mass fraction of the sea-spray, reflecting the minor contribution of organics to the coarse aerosol mode. The GongMonahan function (Gong, 2003) for sea-spray number emission rate $(N)$ was integrated with aerosol radius at $80 \%$ relative humidity $\left(r_{80}\right)$ (Gong et al., 1997) and converted into the super-micron mass emission rate $E_{\text {sup }}\left(\mathrm{ng} \mathrm{m}^{-2} \mathrm{~s}^{-1}\right)$ of marine primary organic aerosols as:

$E_{\text {sup }}=\rho_{a p} * \frac{4}{3} \pi \times 10^{-3} * F_{\text {sup }} * \int_{.5}^{4} N\left(r_{80}\right) * r^{3} d r$

where $F_{\text {sup }}$ is the chlorophyll-dependent mass contribution of OC in super-micron sea-spray aerosols, $\rho_{a p}$ is the bulk density of dry sea-spray particle: $\rho_{a p}=\frac{\rho_{s s}}{1-F_{\text {sup }}\left(1-\frac{\rho_{s s}}{\rho_{\text {org }}}\right)}, r$ is the dry aerosol radius (in $\mu \mathrm{m}$ ), $\rho_{s s}$ is the sea-salt density $\left(2.165 \mathrm{~g} \mathrm{~cm}^{-3}\right)$, and $\rho_{\text {org }}$ is the WIOC density $\left(1 \mathrm{~g} \mathrm{~cm}^{-3}\right)$ (Cavalli et al., 2004). Integration limits with radii from $0.5-$ $4 \mu \mathrm{m}$ correspond to the size range of super-micron particles measured in several marine organic aerosol studies (O'Dowd et al., 2004; Facchini et al., 2008). Despite the dominance of sea-salt in super-micron marine aerosols, it was shown that over the productive region of the North Atlantic Ocean, organic mass contributed $\sim 3 \%$ of $2-4 \mu \mathrm{m}$ radius sea-spray particle mass (Facchini et al., 2008). Using this percent as an estimate of the total super-micron organics, we applied a similar weighting function from O'Dowd et al. (2008) with $F_{\text {sup }}=3 \% F_{\text {sub }}$. The super-micron mass emission rate of marine primary $\mathrm{OC}$ was calculated using an estimated $\mathrm{OC}$ to OM conversion factor of 1.52 reflecting the higher WSOC content of coarse marine organic aerosols (Decesari et al., 2007; Facchini et al., 2008). It is important to note that the calculation of the global super-micron primary OC emission uses an extrapolation of the organic fraction from O'Dowd et al. (2008), and thus should be considered as preliminary.

\section{Results}

Recent studies suggest that physico-chemical properties of marine aerosols can be linked to the observed seasonal cycle of [Chl- $a$ ] in ocean surface waters (Yoon et al., 2007). Based on the vertical concentration gradient measurements of marine aerosols at the coastal research station in Mace Head, Ireland, two distinct production mechanisms for WSOC and WIOC organic carbon were proposed (Ceburnis et al., 2008). It was shown that WIOC had a net production at the surface (i.e., primary production), while WSOC was predominantly of secondary origin. In order to derive global oceanic source of OC, we consider separately primary emissions and SOA production.

\subsection{Global marine isoprene emissions}

Global marine isoprene emissions are calculated hourly for 2001 using Eq. (3) for each $1^{\circ} \times 1^{\circ}$ grid cell and converted to units of molecules $\mathrm{cm}^{-2} \mathrm{~s}^{-1}$ to compare with reported in-situ measurements. Figure 2 shows marine isoprene emission rates in different seasons for the year 2001 , calculated by taking a monthly-mean of the hourly data for January and July. The emissions range from $\sim 5 \times 10^{5}$ to $>6 \times 10^{8}$ molecules $\mathrm{cm}^{-2} \mathrm{~s}^{-1}$, and are comparable to published in-situ emission measurements and modeling results (Bonsang et al., 1992; Milne et al., 1995; Broadgate et al., 1997; Baker et al., 2000; Matsunaga et al., 2002; Broadgate et al., 2004; Greenburg et al., 2005; Palmer and Shaw, 2005; Liakakou et al., 2007; Sinha et al., 2007). The highest emission values are generally estimated during the spring and summer seasons in the midlatitudes (September-March in the Southern Ocean and 
April-August in the North Atlantic/Pacific Ocean); coastal waters affected by upwelling and river runoffs also demonstrate high emission rates. Overall, the emission pattern of Fig. 2 is similar to that of Palmer and Shaw (2005), with the highest rates located in areas of the highest [Chla] (see Fig. S1: http://www.atmos-chem-phys.net/9/4915/ 2009/acp-9-4915-2009-supplement.pdf), though comparison of Figs. 2 and S1 reveals some differences between the surface $[\mathrm{Chl}-a]$ and isoprene emission rates. Compared to mid-latitude regions, widespread areas in tropical waters have relatively low chlorophyll- $a$ abundance, yet these tropical waters show high isoprene emission rates often reaching more than $6 \times 10^{7}$ molecules $\mathrm{cm}^{-2} \mathrm{~s}^{-1}$. Such high emission rates throughout the year are likely to be attributed to the high solar radiation levels. Elevated rates of emissions and water concentrations of isoprene and other BVOC have been observed in several locations in tropical waters, presumably because of the high solar radiation (Bonsang et al., 1988). Comparison of Figs. 2 and S1 shows that marine isoprene production may resemble that of DMS (Toole and Siegel, 2004) having two distinct regimes, stress-forced (where emission rates are mainly driven by high levels of solar radiation) and bloom-forced (where emission rates are mostly related to high phytoplankton abundance).

In order to correctly simulate global marine isoprene SOA in addition to monthly mean emission values, it is very important for the models to correctly capture the diurnal variations of isoprene emissions. Due to the light dependence of isoprene production, it was shown that maximum mid-day emissions of marine isoprene are roughly an order of magnitude higher compared to the nighttime emissions (Sinha et al., 2007). Furthermore, the effects of marine isoprene SOA on properties of shallow marine clouds and the resulting changes in short-wave radiative flux at the top of the atmosphere are likely to be the most pronounced during the daylight conditions (Meskhidze and Nenes, 2006). Therefore, calculating isoprene emissions on a frequency of an hour or less will provide better estimates for the possible contribution of marine OC aerosols to $\mathrm{CCN}$ chemical composition and size distribution. Currently there are few in-situ studies for the diurnal variations of marine isoprene emissions. In Fig. 3, the simulated isoprene emissions between 19 May and 26 May 2001 are compared to in-situ measurements from Matsunaga et al. (2002) from the same period and location. Figure 3 shows that in general, modeled emission rates are comparable to the observations in both magnitude and diurnal variation. However, the figure also shows the small overestimation of oceanic isoprene emissions during the day and strong underestimations at night. Such differences between the simulated and observed emissions are likely to be attributed to the absence of isoprene accumulation in the modeled water column.

In this study we estimate the total global marine isoprene emissions to be $\sim 0.92 \mathrm{Tg} \mathrm{C} \mathrm{yr}^{-1}$, within the wide range of values shown in Table 1 . Such wide range is likely due

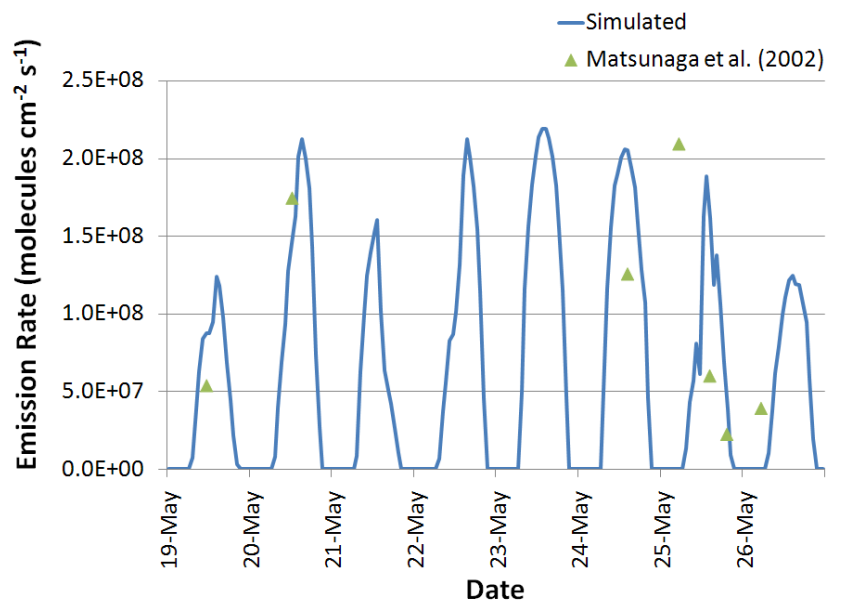

Fig. 3. Comparison of simulated and observed isoprene emission rates in the Northern Pacific Ocean along the ship track of Matsunaga et al. (2002).

to the highly variable physical and biological characteristics of the oceans. Parameters like the mixed layer depth, diffuse attenuation, [Chl- $a$ ], and phytoplankton speciation can greatly vary both spatially and temporally, contributing to large differences in model estimates. Sensitivity calculations for different plankton speciation and water column depths presented in Sect. 4 show an estimated range of global iso-

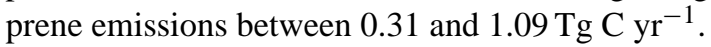

\subsection{Global marine primary organic aerosol emissions}

The sub-micron primary OC emission rates for January and July 2001 are shown in Fig. 4a, b. These figures show that the areas in the mid-latitudes $\left(30^{\circ}\right.$ to $\left.60^{\circ}\right)$ have high emission rates throughout the year. In these regions, primary OC emissions are mainly controlled by high surface ocean winds; emission rates in excess of $10^{10}$ molecules $\mathrm{C}$ $\mathrm{cm}^{-2} \mathrm{~s}^{-1}\left(\sim 2 \mathrm{ng} \mathrm{C} \mathrm{m}^{-2} \mathrm{~s}^{-1}\right)$ are common. The lowest primary $\mathrm{OC}$ emission rates occur in tropical waters, resulting from the relatively low surface wind speed and $[\mathrm{Chl}-a]$. The global distribution of super-micron primary organic aerosol emission rates, shown in Fig. 4c, d, are similar to the submicron emissions but with a higher magnitude, owing to the higher mass of larger particles.

In this study, we estimate global annual ocean emissions for sub- and super-micron primary OC to be about 2.9 and 19.4 Tg C $\mathrm{yr}^{-1}$, respectively. Different assessments for global annual marine OC emissions are summarized in Table 1. The reasons for the large variation in estimates include the limited number of in-situ measurements, the use of different sea-spray functions, and the implementation of distinct methods (modeling vs. remote sensing; bottom-up vs. top-down). 


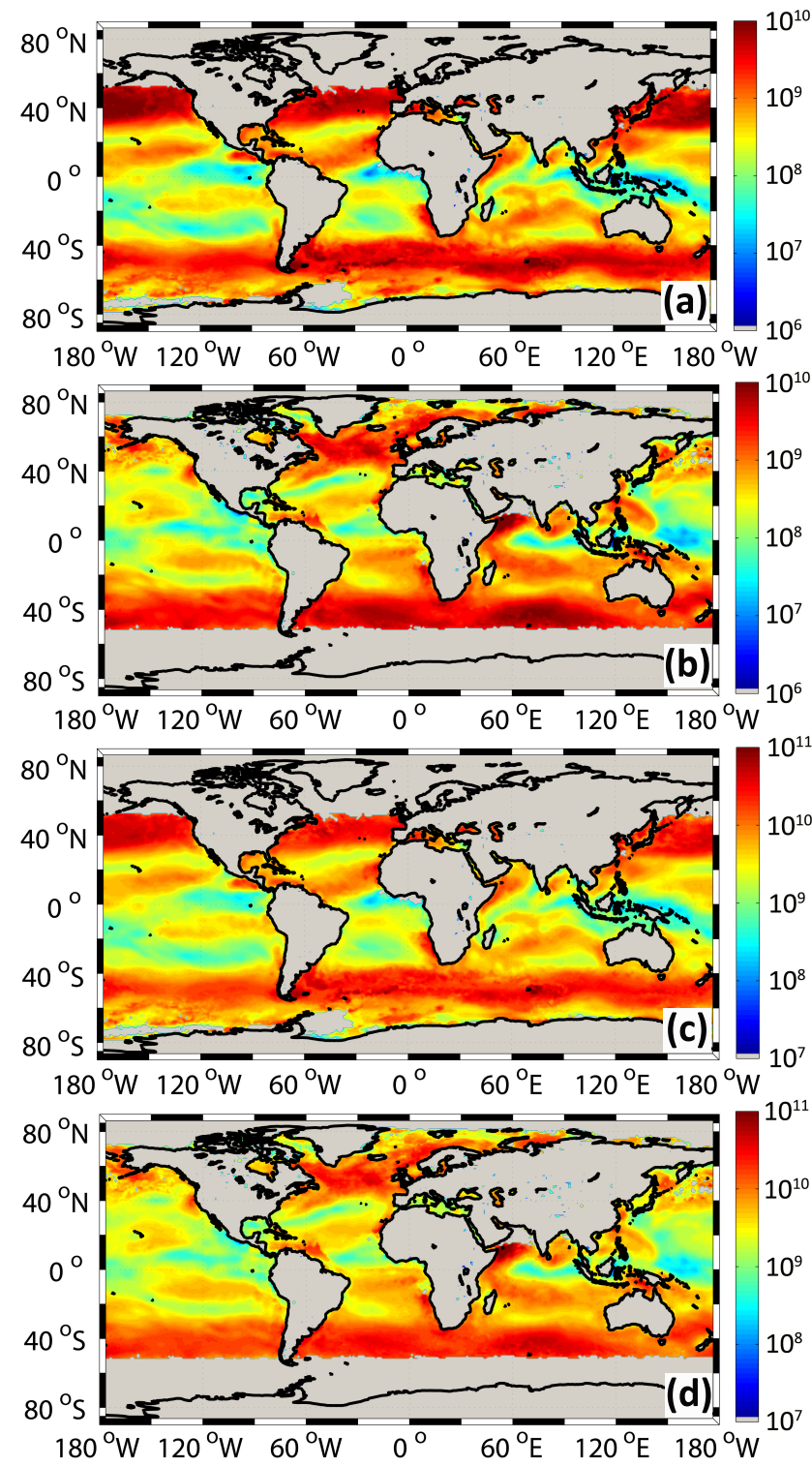

Fig. 4. Monthly-average sub- and super-micron primary OC emission rate (molecules $\mathrm{C} \mathrm{cm}^{-2} \mathrm{~s}^{-1}$ ) for January $(\mathbf{a}, \mathbf{c})$ and July (b, d) 2001 .

\subsection{Relative importance of primary and secondary or- ganic aerosols of marine origin}

The relative contribution of SOA from marine isoprene to the total marine organic aerosol burden has been a topic of discussion in several recent papers (Vaattovaara et al., 2006; Arnold et al., 2009). Dynamic, physically-based emission mechanisms for both primary OC and marine isoprene used in this study allow us to evaluate spatial and temporal distribution of the percentage contribution of marine isoprene SOA to the total simulated marine organic aerosol emissions. Here we focus on total sub-micron OC aerosols (sub-micron

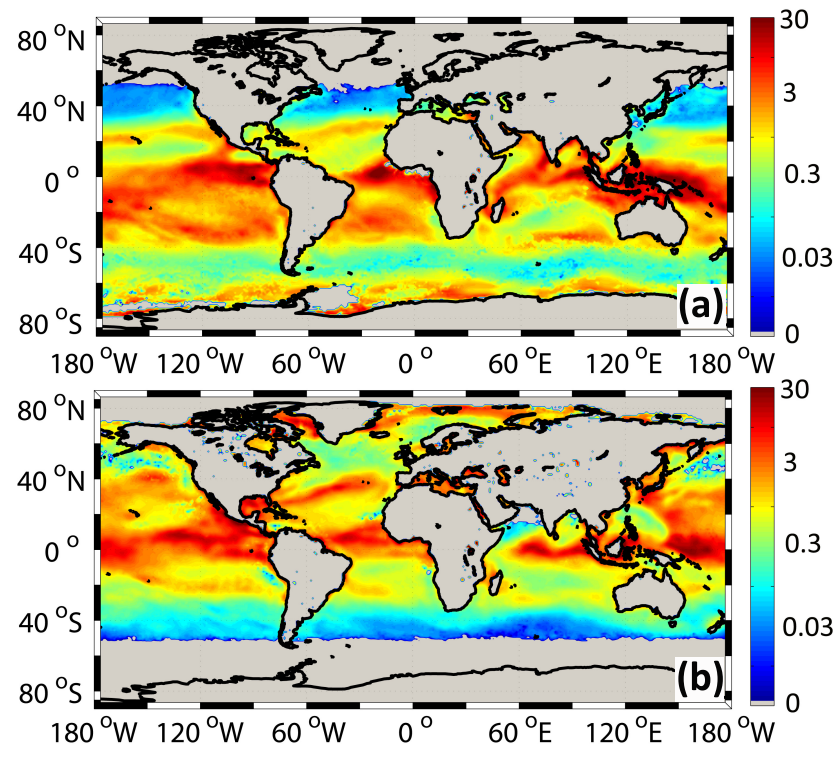

Fig. 5. Monthly-average percentage contribution of marine isoprene SOA to total (primary and secondary) sub-micron marine OC emissions for (a) January and (b) July 2001.

primary $\mathrm{OC}+$ marine isoprene $\mathrm{SOA}$ ) because of their potential influence on $\mathrm{CCN}$ activation of marine aerosols (Nenes et al., 2002; O'Dowd et al., 2004). In order to compare SOA production rates to that of sub-micron primary $\mathrm{OC}$, we assume a $3 \%$ mass yield of isoprene to SOA (Henze and Seinfeld, 2006) and an OC to SOA conversion factor of 1.6 (Turpin et al., 2001). Figure 5a, b shows widespread areas of the tropical oceanic regions where marine isoprene SOA contributes over $30 \%$ of total monthly averaged sub-micron OC emissions. This figure also shows that despite larger ocean emissions of isoprene in productive regions of the North Atlantic, North Pacific and the Southern Oceans (see Fig. 2), monthly-averaged marine isoprene SOA contributes a minor fraction of total marine sub-micron OC in these mid-latitude oceanic regions. Figure 6 shows that the zonally-averaged production rates of marine isoprene SOA are comparable to sub-micron primary $\mathrm{OC}$ aerosols in tropical regions, while in most other locations, marine sources of sub-micron $\mathrm{OC}$ are dominated by primary aerosols. Such high emission rates of sub-micron primary OC (more than an order of magnitude higher than the production rates for marine isoprene SOA) is primarily due to the year round high wind speed in the midlatitude regions. Overall, despite marine isoprene SOA being a minor contributor to the global sub-micron marine aerosol OC fraction (see Table 1), Figures 5 and 6 show that marine isoprene SOA may potentially affect $\mathrm{CCN}$ chemical composition and size distribution over large regions of the global ocean.

In addition to spatial differences, ocean emissions of BVOCs are also characterized by strong diurnal variations 

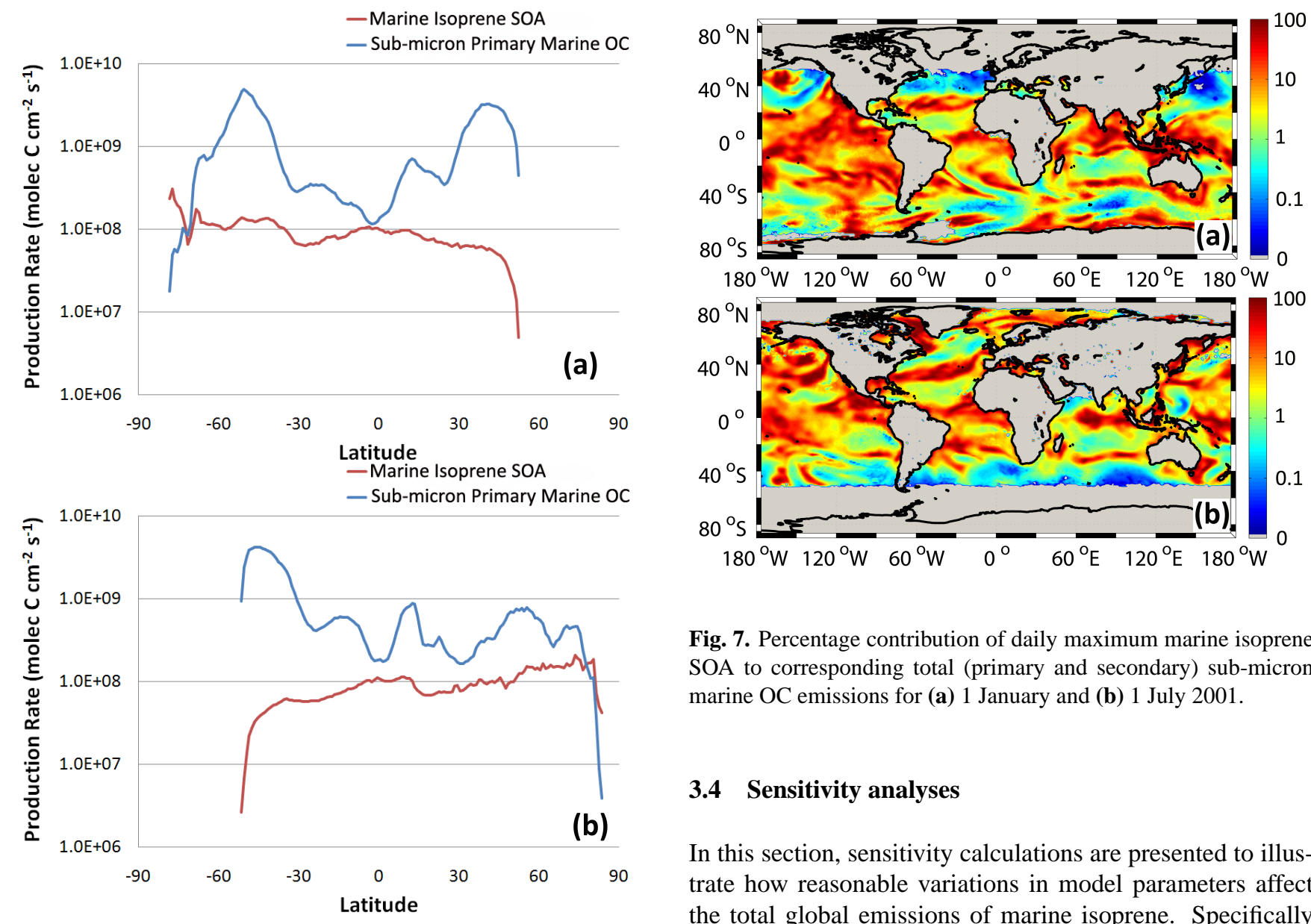

Fig. 7. Percentage contribution of daily maximum marine isoprene SOA to corresponding total (primary and secondary) sub-micron marine OC emissions for (a) 1 January and (b) 1 July 2001.

\subsection{Sensitivity analyses}

In this section, sensitivity calculations are presented to illustrate how reasonable variations in model parameters affect the total global emissions of marine isoprene. Specifically we address model sensitivities to phytoplankton speciation and the extent of water column through which the isoprene production occurs. Phytoplankton speciation was chosen for the analysis because of the substantial differences in isoprene production rates for different groups of phytoplankton reported in Sect. 2.2, and the water column depth was tested due the uncertainty in phytoplankton abundance beyond the one optical depth viewable by satellites. underestimate the contribution of marine isoprene SOA to the total marine OC emissions during the day and overestimate at night. The global maps of Fig. 7 can be interpreted as a "snapshot" for the potential impact of midday marine isoprene SOA production on total sub-micron marine OC emissions. Figure 7 shows that the localized percentage contributions of marine isoprene SOA to the total sub-micron marine OC emissions approach 50\%, even in areas with low monthly-averaged values (i.e., mid-latitude regions). Because emissions of marine isoprene and primary OC aerosols are primarily driven by solar radiation and surface wind speed respectively, the local meteorology plays a large role in determining the percentage contribution of marine isoprene SOA to total OC. Therefore, Fig. 7 shows that marine isoprene emissions at much higher temporal resolution (with time step on the order of an hour) may be required in order for the global models to correctly simulate radiative effect of marine OC aerosols.

\subsection{Phytoplankton speciation}

Two different phytoplankton speciation schemes implemented in this study allow us to examine the impact on marine-source isoprene emission estimates to the uncertainties in the plankton speciation. The primary difference between the two examined methods (i.e., PHYSAT and NDT) is the diatom abundance in the mid-latitude and polar $\left(>60^{\circ} \mathrm{N} / \mathrm{S}\right.$ ) oceanic regions; the NDT method has a large area of diatom abundance, while the PHYSAT method has comparable ratios of nanoeukaryotes, diatoms, coccolithophores, and Phaeocystis-like phytoplankton. Because diatoms produce isoprene at a rate that is roughly $30 \%$ higher compared to other phytoplankton classes (see Fig. 1), the NDT speciation method gives total global annual isoprene emis-

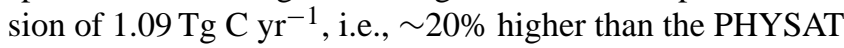


estimate. This finding suggests that the differences in phytoplankton speciation (deduced using two distinct methods) are likely to contribute about $20 \%$ uncertainty in global marine isoprene emissions. These results highlight the need for supplementary in-situ measurements of phytoplankton speciation in different parts of the global ocean.

\subsection{Variable euphotic depth}

For a sensitivity analysis of the effect of euphotic zone estimate on marine-isoprene production, we set $H_{\max }$ to one optically-sensed depth given as: $H_{\max }=k_{490}^{-1}$. When limiting isoprene production to only the first optical depth $(\sim 1 \mathrm{~m}$ to $\sim 50 \mathrm{~m}$ based on the surface ocean [Chl- $a]$ ), the total global annual ocean isoprene emission are reduced to $0.31 \mathrm{Tg} \mathrm{C}$ $\mathrm{yr}^{-1}$. This estimate should be considered as the low limit of isoprene emissions, since it is common for the seawater [Chla] and dissolved isoprene maximum to occur in the mixed layer well below the first optical depth viewable by satellites (Milne et al., 1994).

\section{Conclusion}

A physically-based parameterization for the emission of marine isoprene and primary organic matter was used to estimate and compare the global oceanic sources of OC. In this study, new laboratory measurements of isoprene production by different phytoplankton species under a range of light conditions were performed. The obtained relationship was used in conjunction with remotely sensed data of [Chl- $a]$, phytoplankton speciation and water attenuation of solar downwelling irradiance to simulate, for the first time, the diurnal variation of marine isoprene production in different parts of the global ocean. We estimate the total mean global marine-

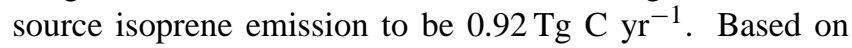
the sensitivity studies using different schemes for the euphotic zone depth and ocean phytoplankton speciation, we propose the upper and the lower range of marine-isoprene emissions to be between 0.31 and $1.09 \mathrm{Tg} \mathrm{C} \mathrm{yr}^{-1}$, respectively. Our simulations reveal, that in addition to [Chl- $a$ ] and mixed layer depth, marine isoprene emission rates strongly depend on plankton speciation and the amount of solar incoming radiation. Such dependence of emission rates on environmental parameters may partially reconcile considerable discrepancies in past global marine isoprene production estimates. Despite comparable results, however, differences remain between observed and our model-predicted marine isoprene emissions, mainly under nighttime conditions. Underprediction of nighttime emissions of marine isoprene in our model is likely to be attributed to the absence of isoprene accumulation mechanism in the water column.

The emission model developed in this study also allowed us to explore the relative contribution of sub- and supermicron organic matter and marine isoprene SOA to the to- tal OC fraction of marine aerosol. Our simulations show that marine isoprene is a minor source of a total global annually emitted marine OC aerosol which we estimate to be $22.3 \mathrm{Tg} \mathrm{C} \mathrm{yr}^{-1}$. However, the importance of marine isoprene SOA becomes apparent when compared to sub-micron primary marine organic aerosol emissions. Sub-micron fraction was chosen for the comparison since it is believed that sub-micron OC potentially influences the $\mathrm{CCN}$ activation of marine aerosols. Our model simulations show that monthlyaveraged marine sub-micron primary OC emissions are considerably higher than that of marine isoprene SOA in most oceanic regions, except in the tropics, where marine isoprene SOA contributes up to $30 \%$ of the total sub-micron $\mathrm{OC}$ fraction of marine aerosol. When midday hourly emission of marine isoprene SOA and sub-micron primary OC are compared, simulations show much larger (approaching 50\%) contribution from marine isoprene SOA over large regions of the oceans. As the effect of marine isoprene SOA is particularly pronounced during the short interval of daylight conditions, an isoprene emission time step on the order of an hour may be required in order for global models to correctly capture its climatic implications. Uncertainties in isoprene production rates, SOA yields, wind fields and the limited sets of observational data are all likely to affect our model-predicted fluxes of primary and secondary marine OC. Despite these limitations, however, we believe that modeling results presented in this study demonstrate that marine isoprene SOA can significantly influence the sub-micron OC burden and potentially lead to changes in $\mathrm{CCN}$ activation properties of marine aerosol.

Cooperative efforts of researchers for in-situ emission measurements of isoprene and other BVOCs over biologically active regions of remote oceans combined with the extensive laboratory-based experiments are needed to gain further insight into the production of isoprene by marine biota and improve global estimates of marine isoprene emissions. Work is also needed to better constrain speciation and column abundances of phytoplankton in estuaries and nearcoastal regions for the detailed, finer scale modeling of the near-coastal emission rates. Recent observations of monoterpene concentrations over the remote oceans (Yassaa et al., 2008; Columb et al., 2009) and the reported production of monoterpenes from phytoplankton monocultures (Yassaa et al., 2008) give additional support for the importance of marine sources of SOA. Future studies should also focus on elucidation of the potential effects of nutrient limitation, bacterial population, and grazing pressure on the rates of marine BVOC production.

Acknowledgements. This research was supported by the Office of Science (BER), US Department of Energy, Grant No. DE-FG0208ER64508. The authors would like to thank Robert Reed of the NCSU Center for Applied Aquatic Ecology for his help with phytoplankton samples, Joshua Hemperly for his help with the Global WRF solar radiation data, Jose Fuentes and Stephen Chan at the University of Virginia for their help running samples using 
the PTR-MS, Severine Alvain for providing the PHYSAT nLw* lookup tables, and Vinayak Sinha for providing isoprene emissions data.

\section{Edited by: W. E. Asher}

\section{References}

Alvain, S., Moulin, C., Dandonneau, Y., and Breon, F. M.: Remote sensing of phytoplankton groups in case 1 waters from global SeaWiFS imagery, Deep-Sea Res. I, 52, 1989-2004, 2005.

Alvain, S., Moulin, C., Dandonneau, Y., and Loisel, H.: Seasonal distribution and succession of dominant phytoplankton groups in the global ocean: A satellite view, Global Biogeochem. Cycles, 22, GB3001, doi:10.1029/2007GB003154, 2008.

Andreae, M. O., Charlson, R. J., Bruynseels, F., Storms, H., Grieken, R. V., and Maenhaut, W.: Internal Mixture of Seasalt, Silicates, and Excess Sulfate in Marine Aerosols, Science, 27, 232(4758), 1620-1623, doi:10.1126/science.232.4758.1620, 1986.

Andreas, E.: A New Sea Spray Generation Function for Wind Speeds up to $32 \mathrm{~m} \mathrm{~s}^{-1}$, J. Phys Oceanography, 28, 2175-2184, 1998.

Arnold, S. R., Spracklen, D. V., Williams, J., Yassaa, N., Sciare, J., Bonsang, B., Gros, V., Peeken, I., Lewis, A. C., Alvain, S., and Moulin, C.: Evaluation of the global oceanic isoprene source and its impacts on marine organic carbon aerosol, Atmos. Chem. Phys., 9, 1253-1262, 2009,

http://www.atmos-chem-phys.net/9/1253/2009/.

Baker, A. R., Turner, S. M., Broadgate, W. J., Thompson, A., McFiggans, G. B., Vesperini, O., Nightingale, P. D., Liss, P. S., and Jickells, T. D.: Distribution and sea-air fluxes of biogenic trace gases in the eastern Atlantic Ocean, Global Biogeochem. Cycles, 14, 871-886, 2000.

Blanchard, D. C.: Sea to air transport of surface active material, Science, 146, 396-397, doi:10.1126/science.146.3642.396, 1964.

Blondeau-Patissier, D., Tilstone, G. H., Martinez-Vicente, V., and Moore, G. F.: Comparison of bio-physical marine products from SeaWiFS, MODIS, and a bio-optical model with in-situ measurements from Northern European waters, J. Opt. A: Pure Appl. Opt., 6, 875-889, 2004.

Bonsang, B., Kanakidou, M., Lambert, G., and Monfray, P.: The marine source of C2-C6 aliphatic hydrocarbons, J. Atmos. Chem., 6, 3-20, 1988.

Bonsang, B., Polle, C., and Lambert, G.: Evidence for marine production of isoprene, Geophys. Res. Lett., 19, 1129-1132, 1992.

Broadgate, W. J., Liss, P. S., and Penkett, S. A.: Seasonal emissions of isoprene and other reactive hydrocarbon gases from the ocean, Geophys. Res. Lett., 24, 2675-2678, 1997.

Broadgate, W., Malin, G., Kupper, F., Thompson, A., and Liss, P.: Isoprene and other non-methane hydrocarbons from seaweeds: a source of reactive hydrocarbons to the atmosphere, Mar. Chem., 88(1-2), 61-73, 2004.

Cavalli, F., Facchini, M. C., Decesari, S., Mircea, M., Emblicia, L., Fuzzi, S., Ceburnis, D., Yoon, Y. J., O’Dowd, C. D., Putaud, J.P., and Dell'Acqua, A.: Advances in characterization of size resolved organic matter in marine aerosol over the North Atlantic, J. Geophys. Res., 109, D24215, doi:10.1029/2004JD005137, 2004.
Ceburins D., O’Dowd, C., Jennings, G. S., Facchini, M. C., Emblico, L., Decesari, S., Fuzzi, S., and Sakalys, J.: Marine aerosol chemistry gradients: Elucidating primary and secondary processes and fluxes, Geophys. Res. Let., 35, L07804, doi:10.1029/2008GL033462, 2008.

Charlson, R. J., Lovelock, J. E., Andreae, M. O., and Warren, S. G.: Oceanic phytoplankton, atmospheric sulfur, cloud albedo and climate, Nature, 326, 655-661, 1987.

Claeys, M. B., Graham, G., Vas, W., Wang, R., Vermeylen, V., Pashynska, Cafmeyer, J., Guyon, P., Andreae, M. O., Artaxo, P., and Maenhaut, W.: Formation of Secondary organic aerosols through photooxidation of isoprene, Science, 303, 1173-1176, 2004.

Colomb, A., Yassaa, N., Williams, J., Peeken, I., and Lochte, K.: Screening volatile organic compounds (VOCs) emissions from five marine phytoplankton species by head space gas chromatography/mass spectrometry (HS-GC/MS), J. Environ. Monit., 10(3), 325-330, 2008.

Colomb, A., Gros, V., Alvain, S., Sarda-Esteve, R., Bonsang, B., Moulin, C., Klüpfel, T., Williams, J.: Variation of atmospheric volatile organic compounds over the Southern Indian Ocean (30-49 ${ }^{\circ}$ S), Environ. Chem., 6(1), 70-82, doi:10.1071/EN08072, 2009.

Decesari, S., Facchini, M. C., Mircea, M., Cavalli, F., Emblico, L., Fuzzi, S., Moretti, F., and Tagliavini, E.: Source attribution of water-soluble organic aerosol by nuclear magnetic resonance spectroscopy, Environ. Sci. Technol., 41, 2479-2484, 2007.

Edney, E. O., Kleindienst, T. E., Jaoui, M., Lewandowski, M., Offenberg, J. H., Wang, W., and Claeys, M.: Formation of 2-methyl tetrols and 2-methylglyceric acid in secondary organic aerosol from laboratory irradiated isoprene/ $/ \mathrm{NO}_{\mathrm{X}} / \mathrm{SO}_{2} /$ air mixtures and their detection in ambient $\mathrm{PM}_{2.5}$ samples collected in the eastern United States, Atmos. Environ., 39, 5281-5289, 2005.

Ervens B., Carlton, A. G., Turpin, B. J., Altieri, K. E., Kreidenweis, S. M., and Feingold, G.: Secondary organic aerosol yield from cloud-processing of isoprene oxidation products, Geophys. Res. Lett., 35, L02816, doi:10.1029/2007GL031828, 2008.

Facchini M. C., Rinaldi, M., Decesari, S., Carbone, C., Finessi, E., Mircea, M., Fuzzi, S., Ceburnis, D., Flanagan, E., Nilsson, D., Leeuw, G., Martino, M., Woeltjen J., and O'Dowd, C. D.: Primary sub-micron marine aerosol dominated by insoluble organic colloids and aggregates, Geophys. Res. Lett., 35, L17814, doi:10.1029/2008GL034210, 2008.

Geron, C., Guenther, A., Greenberg, J., Karl, T., and Rasmussen, R.: Biogenic volatile organic compound emissions from desert vegetation of the southwestern US, Atmos. Environ., 40, 16451660, 2006.

Gershey, R. M.: Characterization of seawater organic matter carried by bubble-generated aerosols, Limnol. Oceanogr., 28, 309-319, 1983.

Gong, S. L., Barrie, L. A., and Blanchet, J.-P.: Modeling sea-salt aerosols in the atmosphere 1. Model development, J. Geophys. Res., 102, 3805-3818, 1997.

Gong, S. L.: A parameterization of sea-salt aerosol source function for sub- and super- micron particles, Global Biogeochemical Cycles, 17(4), 1097, doi:1029/2003GB002079, 2003.

Greenberg, J. P., Guenther, A. B., and Turnipseed, A.: Marine organic halide and isoprene emissions near mace head, Ireland, Environ. Chem., 2, 291-294, doi:10.1071/EN05072, 2005. 
Guenther, A. B., Monson, R. K., and Fall, R.: Isoprene and monoterpene emission rate variability: observations with Eucalyptus and emission rate algorithm development, J. Geophys. Res., 96, 10799-10808, 1991.

Guenther, A. B., Zimmerman, P. R., and Harley, P. C.: Isoprene and monoterpene emission rate variability: model evaluations and sensitivity analysis, J. Geophys. Res., 98, 12609-12617, 1993.

Henze, D. K. and Seinfeld, J. H.: Global secondary organic aerosol from isoprene oxidation, Geophys. Res. Lett., 33, L09812, doi:10.1029/2006GL025976, 2006.

Holm-Hansen, D. and Riemann, B.: Chlorophyll $a$ determination: improvements in methods, Oikos, 30, 438-447, 1978.

Jacovides, C. P., Tymvios, F. S., Papaioannou, G., Asimakopoulos, D. N., and Theofilou, C. M.: Ratio of PAR to broadband solar radiation measured in Cyprus. Agric. Forest Meteorol. 121, 135140, 2004.

Kamykowski, D., Zentara, S. J., Morrison, J. M., and Switzer, A. C.: Dynamic global patters of nitrate, phosphate, silicate, and iron availability and phytoplankton community composition from remotely sensing data, Global Biogeochem. Cycles, 16(4), 1077, doi:10.1029/2001GB001640, 2002.

Kroll, J. H., Ng, N. L., Murphy, S. M., Flagan, R. C., and Seinfeld, J. H.: Secondary organic aerosol formation from isoprene photooxidation under high-NOx conditions, Geophys. Res. Lett., 32, L18808, doi:10.1029/2005GL023637, 2005.

Kroll, J. H., Ng, N. L., Murphy, S. M., Flagan, R. C., and Seinfeld, J. H.: Secondary organic aerosol formation from isoprene photooxidation, Environ. Sci. Technol., 40, 1869-1877, doi:10.1021/es0524301, 2006.

Langmann, B., Scannell, C., and O’Dowd, C.: New Directions: Organic matter contribution to marine aerosols and cloud condensation nuclei, Atmos. Environ., 42, 7821-7822, 2008.

Lewis, A. C., Carpenter, L. J., and Pilling, M. J.: Nonmethane hydrocarbons in Southern Ocean boundary layer air, J. Geophys. Res., 106(D5), 4987-4994, 2001.

Liakakou, E., Vrekoussis, M., Bonsang, B., Donousis, Ch., Kanakidou, M., and Mihalopoulos, N.: Isoprene above the Eastern Mediterranean: Seasonal variation and contribution to the oxidation capacity of the atmosphere, Atmos. Environ., 41(5), 10021010, doi:10.1016/j.atmosenv.2006.09.034, 2007.

Matsunaga, S., Mochida, M., Saito, T., and Kawamura, K.: In-situ measurement of isoprene in the marine air and surface seawater from the western North Pacific, Atmos. Environ., 36, 6051-6057, 2002.

Meskhidze, N. and Nenes, A.: Phytoplankton and cloudiness in the Southern Ocean, Science, 314, 1419-1423, doi:10.1126/science.1131779, 2006.

Middlebrook, A. M., Murphy, D. M., and Thomson, D. S.: Observations of organic material in individual marine particles at Cape Grim during the First Aerosol Characterization Experiment (ACE-1), J. Geophys. Res., 103, 16475-16483, 1998.

Milne, P. J., Riemer, D. D., Zika, R. G., and Brand, L. E.: Measurement of vertical distribution of isoprene in surface seawater, it chemical fate, and its emission from several phytoplankton monocultures, Mar. Chem., 48, 237-244, 1995.

Nenes, A., Charlson, R. J., Facchini, M. C., Kulmala, M., Laaksonen, A., and Seinfeld, J. H.: Can chemical effects on cloud droplet number rival the first indirect effect?, Geophys. Res. Lett., 29(17), 1848, doi:10.1029/2002GL015295, 2002.
Ng, N. L., Kwan, A. J., Surratt, J. D., Chan, A. W. H., Chhabra, P. S., Sorooshian, A., Pye, H. O. T., Crounse, J. D., Wennberg, P. O., Flagan, R. C., and Seinfeld, J. H.: Secondary organic aerosol (SOA) formation from reaction of isoprene with nitrate radicals $\left(\mathrm{NO}_{3}\right)$, Atmos. Chem. Phys., 8, 4117-4140, 2008,

http://www.atmos-chem-phys.net/8/4117/2008/.

Novakov, T., Corrigan, C. E., Penner, J. E., Chuang, C. C., Rosario, O., and Mayel Bracero, O. L.: Organic aerosols in the Caribbean trade winds: A natural source?, J. Geophys. Res., 102, 2130723313, 1997.

O’Dowd, C. D., Lowe, J. A., and Smith, M. H.: Marine aerosol, sea-salt, and the marine sulphur cycle: A short review, Atmos. Environ., 31, 73-80, 1997.

O’Dowd, C. D., Hameri, K., Makela, J. M., Pirjola, L., Kulmala, M., Jennings, S. G., Berresheim, H., Hansson, H. C., de Leeuw, G., Kunz, G. J., Allen, A. G., Hewitt, C. N., Jackson, A., Viisanen, Y., and Hoffmann, T.: A dedicated study of new particle formation and fate in the coastal environment (PARFORCE): overview of objectives and initial achievements, J. Geophys. Res. 107(D19), 8108, doi:10.1029/2001JD000555, 2002.

O’Dowd, C. D., Facchini, M. C., Cavalli, F., Ceburnis, D., Mircea, M., Decesari, S., Fuzzi, S., Yoon, Y. J., and Putaud, J. P.: Biogenically driven organic contribution to marine aerosol, Nature, 431, 676-680, 2004.

O’Dowd, C. D. and de Leeuw, G.: Marine aerosol production: a review of the current knowledge, Phil. Trans. R. Soc. A, 365, 1753-1774, 2007.

O’Dowd, C. D., Langmann, B., Varghese, S., Scannell, C., Ceburnis, D., and Facchini, M. C.: A combined organic-inorganic sea-spray source function, Geophys. Res. Let., 35, L01801, doi:10.1029/2007GL030331, 2008.

O’Reilly, J. E., Maritorena, S., Mitchell, B. G., Siegel, D. A., Carder, K. L., Garver, S. A., Kahru, M., and McClain, C.: Ocean color chlorophyll algorithms for SeaWiFS, J. Geophys. Res., 103(C11), 24937-24953, 1998.

Palmer, P. I. and Shaw, S. L.: Quantifying global marine isoprene fluxes using MODIS chlorophyll observations, J. Geophys. Res., 32, L09805, doi:10.1029/2005GL022592, 2005.

Pio, C. A., Legrand, M., Oliveira, T., Afonso, J., Santos C., Caseiro, A., Fialho, P., Barata, F., Puxbaum, H., Sanchez-Ochoa, A., Kasper-Giebl, A., Gelencse'r, A., Preunkert, S., and Schock, M.: Climatology of aerosol composition (organic versus inorganic) at nonurban sites on a west-east transect across Europe, J. Geophys. Res., 112, D23, doi:10.1029/2006JD008038, 2007.

Putaud, J. P., Van Dingenen, R., Mangoni, M., et al.: Chemical mass closure and assessment of the origin of the sub-micron aerosol in the marine boundary layer and the free troposphere at Tenerife during ACE-2, Tellus, Ser. B, 52(2), 141-168, 2000.

Richardson, M. I., Toigo, A. D., and Newman, C. E.: PlanetWRF: A general purpose, local to global numerical model for planetary atmospheric and climate dynamics, J. Geophys. Res., 112, E09001, doi:10.1029/2006JE002825, 2007.

Roelofs, G. J.: A GCM study of organic matter in marine aerosol and its potential contribution to cloud drop activation, Atmos. Chem. Phys., 8, 709-719, 2008, http://www.atmos-chem-phys.net/8/709/2008/.

Shaw, G. E.: Bio-controlled thermostasis involving the sulfur cycle, Clim. Change, 5, 297-303, 1983.

Shaw, S. L., Chisholm, S. W., and Prinn, R. G.: Isoprene production 
by Prochlorococcus, a marine cyanobacterium, and other phytoplankton, Mar. Chem., 80, 227-245, 2003.

Sinha, V., Williams, J., Meyerhfer, M., Riebesell, U., Paulino, A. I., and Larsen, A.: Air-sea fluxes of methanol, acetone, acetaldehyde, isoprene and DMS from a Norwegian fjord following a phytoplankton bloom in a mesocosm experiment, Atmos. Chem. Phys., 7, 739-755, 2007, http://www.atmos-chem-phys.net/7/739/2007/.

Smith, M. and Harrison, N.: Marine aerosols concentrations and estimated fluxes over the sea, J. Aerosol Sci., 29, Suppl. 1, S189S190, 1998.

Spracklen, D. V., Arnold, S. R., Sciare, J., Carslaw, K. S., and Pio, C.: Globally significant oceanic source of organic carbon aerosol, Geophys. Res. Lett., 35, L12811, doi:10.1029/2008GL033359, 2008.

Tokarczyk, R. and Moore, R.: Production of volatile organohalogens by phytoplankton cultures, Geophys. Res. Lett., 21, 285288, 1994

Toole, D. A. and Siegel, D. A.: Light-driven cycling of dimethylsulfide (DMS) in the Sargasso Sea: Closing the loop, Geophys. Res. Lett., 31, L09308, doi:10.1029/2004GL019581, 2004.
Turpin, B. J. and Lim, H.-J.: Species Contributions to $\mathrm{PM}_{2.5}$ Mass Concentrations: Revisiting Common Assumptions for Estimating Organic Mass, Aero. Sci. Technol., 35(1), 602-610, 2001.

Vaattovaara, P., Huttunen, P. E., Yoon, Y. J., Joutsensaari, J., Lehtinen, K. E. J., O'Dowd, C. D., and Laaksonen, A.: The composition of nucleation and Aitken modes particles during coastal nucleation events: evidence for marine secondary organic contribution, Atmos. Chem. Phys., 6, 4601-4616, 2006, http://www.atmos-chem-phys.net/6/4601/2006/.

Yassaa, N., Peeken, I., Zöllner, E., Bluhm, K., Arnold, S., Spracklen, D., and Williams, J.: Evidence for marine production of monoterpenes, Environ. Chem., 5, 391-401, doi:10.1071/EN08047, 2008.

Yoon, Y. J., Ceburnis, D., Cavalli, F., et al.: Seasonal characteristics of the physiochemical properties of North Atlantic marine atmospheric aerosols, J. Geophys. Res., 112, D04206, doi:10.1029/2005JD007044, 2007. 